\title{
MITOMYCIN-C CONCENTRATION IN HUMAN AQUEOUS HUMOUR FOLLOWING TRABECULECTOMY
}

\author{
STEVE K. L. SEAH ${ }^{1,2}$, JOÃO A. PRATA, JR. ${ }^{1,3}$, DON S. MINCKLER ${ }^{1}$, ROBERT T. KODA $^{4}$, \\ GEORGE BAERVELDT ${ }^{4}$, PAUL P. LEE and DALE K. HEUER ${ }^{1}$ \\ Los Angeles, California; Singapore; and Sao Paulo, Brazil
}

\begin{abstract}
SUMMARY
The aim of the study was to determine mitomycin-C (MMC) concentrations in human aqueous humour during trabeculectomy and to correlate anterior chamber concentrations with method of application. MMC was applied intra-operatively by saturating sponges, ranging in size from $2 \times 2 \times 5 \mathrm{~mm}$ to $2 \times 4 \times 10 \mathrm{~mm}$ on dry cut, with $0.5 \mathrm{mg} / \mathrm{ml} \mathrm{MMC} \mathrm{during} \mathrm{trabeculectomy} \mathrm{for} \mathrm{3-5}$ minutes. Applications to episclera were made in 18 cases and to the scleral bed after scleral flap dissection in 9 cases. Aqueous samples were collected by paracentesis with a 30 gauge needle 2-7 minutes after removal of sponge and external irrigation. Aqueous MMC concentrations were determined by high-performance liquid chromatography. Aqueous MMC concentration in 27 samples ranged from below minimum detectable concentration (less than $5 \mathrm{ng} / \mathrm{ml}$ ) to $120.8 \mathrm{ng} / \mathrm{ml}$. Mean aqueous drug levels obtained when the applications were to the scleral bed were $35.65 \pm 39.17 \mathrm{ng} / \mathrm{ml}$ (range 5-120.8 ng/ $\mathrm{ml})$. Applications on episclera gave mean aqueous concentrations of $4.98 \pm 9.11 \mathrm{ng} / \mathrm{ml}$ (range $0-33.3 \mathrm{ng} / \mathrm{ml}$ ). The difference was statistically significant $(p=\mathbf{0 . 0 0 4})$. There were no correlations between sponge size, time of MMC exposure and aqueous MMC level. In conclusion, MMC is detectable in aqueous humour within minutes of external application and the aqueous concentration level is higher if the application is in the scleral bed than on the episclera. Toxicity of the drug at this concentration range for corneal endothelial cells needs further investigation via in vitro and clinical studies.
\end{abstract}

Mitomycin-C (MMC) is an antibiotic agent isolated from Streptomyces caespitosus ${ }^{1,2}$ that acts as a non-cell-cyclespecific alkylating agent. ${ }^{3}$ It has been used systemically for many years for its broad spectrum of anti-tumour

From: 'Doheny Eye Institute, Department of Ophthalmology, University of Southern California School of Medicine, Los Angeles, California, USA; ${ }^{2}$ Singapore National Eye Centre; ${ }^{3}$ Escola Paulista de Medicina, Department of Ophthalmology, Sao Paulo, Brazil; ${ }^{4}$ University of Southern California School of Pharmacy, Los Angeles, California, USA.

Correspondence to: Steve K. L. Seah, FRCS, Singapore National Eye Centre, 11 Third Hospital Avenue, Singapore 0316. activity. In ophthalmology MMC has been used topically to suppress recurrence after pterygium surgery, ${ }^{4-6}$ to decrease the risk of glaucoma filtration bleb failure, ${ }^{7-9}$ and as a modulator of corneal wound healing following excimer photorefractive surgery. ${ }^{10}$

In trabeculectomy, MMC applied intra-operatively at the filtration site reduces subconjunctival scarring and enhances the success rate ${ }^{7-9}$ while causing few intraocular complications. ${ }^{9.11,12}$ MMC does, however, have the potential for endothelial toxicity, as demonstrated by Derick and co-workers, ${ }^{3}$ who injected MMC intracamerally in rabbit eyes. They reported that small amounts of MMC can be harmful to corneal endothelial cells if it gains entry to the anterior chamber during surgery. Serious complications related to local ocular toxicity, such as scleral and corneal ulceration, scleromalacia, necrotising scleritis, uveitis, symblepharon and scleral calcification, are reported following topical use of MMC in pterygium surgery. ${ }^{6,14-17}$ Due to the relatively short clinical experience, the safety of this drug in glaucoma filtration surgery has not been investigated extensively. To our knowledge, the actual concentration of MMC in human aqueous humour following its application during trabeculectomy has not been determined. In the study described here we determined MMC concentrations in human aqueous samples collected intra-operatively and correlated the concentration levels with various methods of application.

\section{PATIENTS AND METHODS}

Twenty-seven patients with medically uncontrolled glaucoma, who required trabeculectomy with adjunctive MMC therapy between 28 October 1992 and 5 February 1993 were studied. Not included were patients who refused consent and those with pre-existing shallow anterior chambers.

Standard trabeculectomy was performed by one of four experienced glaucoma surgeons (D.S.M., G.B., D.K.H. or P.P.L.) at the Doheny Eye Institute. Surgical techniques were similar in all cases except for variations in the method for MMC application. Sponges (Mentor, Norwell, 
Mass., USA), with sizes ranging from $2 \times 2 \times 5 \mathrm{~mm}$ to $2 \times 4 \times 10 \mathrm{~mm}$ on dry cut, were saturated thoroughly in a solution of $0.5 \mathrm{mg} / \mathrm{ml}$ of MMC (Bristol Laboratories, Evansville, Ind., USA) prior to application. A MMCsoaked sponge was placed directly on the episclera before the scleral dissection in 18 cases, and in the scleral bed after dissection of the scleral flap in 9 cases. The sponge remained in place for 3 minutes in 8 cases and 5 minutes in 19 cases. The size of sponge, site of application and duration of exposure were determined by the surgeon's preference. The study protocol was approved by the University of Southern California School of Medicine Research Committee (research protocol no. 92B003), and all patients gave informed consent. Aqueous humour samples $(50-150 \mu \mathrm{l})$ were collected by paracentesis using a 30 gauge needle on a tuberculin syringe 2-7 minutes after removal of the sponge and following copious external irrigation. The samples were stored immediately at $-70^{\circ} \mathrm{C}$ and $\mathrm{MMC}$ concentrations were determined by a specific high-performance liquid chromatographic (HPLC) method within 48 hours of collection.

\section{HPLC Method for Determination of MMC in Aqueous Humour ${ }^{18-21}$}

MMC was determined in aqueous humour by a modification of the HPLC method of Buice et al. ${ }^{18}$ A solution of the internal standard, $p$-aminoacetophenone, $5 \mu \mathrm{g} / \mathrm{ml}$ was added to $100 \mu \mathrm{l}$ of aqueous humour and the mixture shaken. An appropriate volume of this solution was injected directly into the HPLC and separated using a $4.6 \times 50 \mathrm{~mm}, 3 \mu \mathrm{m}$ particle size, C18 reverse-phase column (Microsorb 'Short One'), preceded by a C18 guard column (both Microsorb C18, Rainin Instruments, Woburn, Mass., USA), and detected at an analytical wavelength of $365 \mathrm{~nm}$. The mobile phase consisted of a mixture of methanol:water (28:72), containing $10 \mathrm{mM}$ ammonium hydrogen phosphate, adjusted to $\mathrm{pH}$ 7.0.

The retention times for MMC and internal standard were 2.69 and 2.34 minutes respectively. The validated method was linear over a concentration range of 6-250 $\mathrm{ng} / \mathrm{ml}$, with a minimum detectable concentration in aqueous humour of $5 \mathrm{ng} / \mathrm{ml}$.

\section{Estimation of MMC Dose Delivered During Intra- operative Applications}

The amount of MMC saturated in each piece of sponge (dose) used in applications during surgery was estimated to be $0.47 \mu \mathrm{g} / \mathrm{mm}^{3}$, on the basis of the mean weight difference between a wet and a dry sponge. MMC dose for sponge size $2 \times 2 \times 5 \mathrm{~mm}$ was approximately $9.4 \mu \mathrm{g}$, for $2 \times 4 \times 6 \mathrm{~mm}$ was $22.6 \mu \mathrm{g}$, for $2 \times 5 \times 6 \mathrm{~mm}$ was $28.2 \mu \mathrm{g}$, and for $2 \times 4 \times 10 \mathrm{~mm}$ was $3.76 \mu \mathrm{g}$.

\section{Statistical Method}

Student's $t$-test was used to compare the difference between various test groups. A $p$ value of less than 0.05 was considered statistically significant.

\section{RESULTS}

Patients ranged in age from 2 to 85 years (mean \pm SD,
$56.65 \pm 20.16$ years). Fourteen patients had primary open angle glaucoma, 4 had angle closure glaucoma, 4 had pseudophakic glaucoma, 3 had secondary glaucoma, 1 had neovascular glaucoma and 1 had congenital glaucoma. Only 1 patient had an intra-operative complication: vitreous loss, after iridectomy, several minutes after aqueous sampling.

Aqueous MMC concentrations from the 27 cases are summarised in Table I. The mean aqueous drug concentration after an episcleral application was $4.98 \pm 9.11$ $\mathrm{ng} / \mathrm{ml}$ (range $0-33.3 \mathrm{ng} / \mathrm{ml}$ ), whereas that following scleral bed application was $35.65 \pm 39.17 \mathrm{ng} / \mathrm{ml}$ (range $5-120.8 \mathrm{ng} / \mathrm{ml})$. The difference between the means of the two groups is statistically significant $(p=0.004)$. Statistical comparison of other variables including age, exposure time, size of sponge and collection time showed no significant differences between the two groups ( $p=0.51$, $0.4,0.54$ and 0.15 respectively). Among all the episcleral application cases, there was no correlation between the sponge size, time of application and the aqueous MMC level $(p=0.80)$.

\section{DISCUSSION}

We have demonstrated that MMC is detectable in human aqueous humour within minutes after external application to the sclera. The mean concentration following scleral bed application $(35.65 \mathrm{ng} / \mathrm{ml})$ is slightly lower than that reported by Kawase and co-workers ${ }^{21}$ in their experimental study on rabbit eyes despite the higher drug concentration used in our study $(0.5 \mathrm{mg} / \mathrm{ml}$ vs. $0.2 \mathrm{mg} / \mathrm{ml})$. This difference may have related to the timing of aqueous sample collection. The collection time in our study was between 2 and 7 minutes after removal of the sponge, which may be before the peak concentration is achieved. In their rabbit study, Kawase $e t a l .{ }^{21}$ showed concentration levels in aqueous of $0,90,110,30,20$ and $0 \mathrm{ng} / \mathrm{ml}$ at 0,30 , $60,120,180$ and 360 minutes, respectively, with the peak at 30-60 minutes after application. MMC requires time to diffuse through the ocular tissues to reach peak concentrations in aqueous humour; after this the concentration declines over time, presumably as it is being cleared via the surgical filtration channel, trabecular meshwork and other outflow pathways.

The range of concentrations varies widely in our samples because the concentration level is influenced by many factors, including MMC dose, concentration of drug used, duration of exposure, site of application and perhaps anatomical or physiological variations. The method of MMC application used by some of the surgeons involved in the present study is a modification of that described in the literature..$^{7-9,11,12,22}$ In 18 of our cases the sponge was placed on the episclera prior to scleral flap dissection, and in 9 of the cases application was made after scleral flap dissection, with the sponges placed either on or under the scleral flap, as described in the literature..$^{7-9,11,12,22}$ Lower concentrations of MMC in the aqueous were achieved with the episcleral application method.

The effects, if any, on corneal endothelial cells of MMC 
Table I. Summary of results

\begin{tabular}{|c|c|c|c|c|c|c|c|}
\hline Patient no. & Age (yr) & Diagnosis & Exposure time (min) & MMC dose $(\mu \mathrm{g})$ & Sponge size $(\mathrm{mm})$ & Collection time (min) & Aqueous MMC conc. (ng/ml) \\
\hline \multicolumn{8}{|c|}{ Episclera application } \\
\hline 1 & 52 & ACG & 5 & 28.2 & $2 \times 5 \times 6$ & 2 & $0^{\mathrm{a}}$ \\
\hline 2 & 33 & POAG & 5 & 37.6 & $2 \times 5 \times 8$ & 2 & 0 \\
\hline 3 & 66 & NVG & 5 & 37.6 & $2 \times 5 \times 8$ & 7 & 33.3 \\
\hline 4 & 57 & CMG & 5 & 37.6 & $2 \times 5 \times 8$ & 5 & 0 \\
\hline 5 & 38 & TG & 5 & 28.2 & $2 \times 5 \times 6$ & 5 & 22.0 \\
\hline 6 & 74 & POAG & 5 & 37.6 & $2 \times 5 \times 8$ & 5 & 0 \\
\hline 7 & 69 & POAG & 5 & 37.6 & $2 \times 5 \times 8$ & 5 & 0 \\
\hline 8 & 65 & PXG & 3 & 22.6 & $2 \times 4 \times 6$ & 4 & 0 \\
\hline 9 & 42 & POAG & 3 & 22.6 & $2 \times 4 \times 6$ & 2 & 0 \\
\hline 10 & 84 & PPG & 5 & 37.6 & $2 \times 5 \times 8$ & 5 & 6.4 \\
\hline 11 & 78 & POAG & 5 & 37.6 & $2 \times 4 \times 10$ & 2 & 5.0 \\
\hline 12 & 44 & ACG & 5 & 37.6 & $2 \times 4 \times 10$ & 5 & 0 \\
\hline 13 & 52 & $\mathrm{TG}$ & 3 & 22.6 & $2 \times 4 \times 6$ & 5 & 6.3 \\
\hline 14 & 2 & CG & 5 & 37.5 & $2 \times 4 \times 10$ & 4 & 0 \\
\hline 15 & 68 & POAG & 3 & 22.6 & $2 \times 4 \times 6$ & 5 & 0 \\
\hline 16 & 74 & POAG & 3 & 22.6 & $2 \times 4 \times 6$ & 6 & 5.1 \\
\hline 17 & 73 & POAG & 3 & 22.6 & $2 \times 4 \times 6$ & 7 & 11.5 \\
\hline 18 & 12 & POAG & 3 & 37.6 & $2 \times 4 \times 10$ & 3 & 0 \\
\hline \multicolumn{8}{|c|}{ Scleral bed application } \\
\hline 1 & 68 & ACG & 5 & 37.6 & $2 \times 4 \times 10$ & 4 & 120.8 \\
\hline 2 & 85 & PPG & 3 & 37.6 & $2 \times 5 \times 8$ & 5 & 25.2 \\
\hline 3 & 60 & POAG & 5 & 37.6 & $2 \times 5 \times 8$ & 5 & 19.2 \\
\hline 4 & 66 & PPG & 5 & 9.4 & $2 \times 2 \times 5$ & 6 & 66.1 \\
\hline 5 & 77 & PPG & 5 & 37.6 & $2 \times 5 \times 8$ & 5 & 5.0 \\
\hline 6 & 46 & POAG & 5 & 37.6 & $2 \times 5 \times 8$ & 5 & 59.1 \\
\hline 7 & 51 & SG & 3 & 22.6 & $2 \times 4 \times 6$ & 5 & 11.1 \\
\hline 8 & 32 & POAG & 5 & 22.6 & $2 \times 4 \times 6$ & 5 & 9.4 \\
\hline \multirow[t]{2}{*}{9} & 58 & POAG & 5 & 22.6 & $2 \times 4 \times 6$ & 5 & 5.0 \\
\hline & & & NS & NS & NS & NS & $p=0.004$ \\
\hline
\end{tabular}

ACG, angle closure glaucoma; POAG, primary open angle glaucoma; NVG, neovascular glaucoma; CMG, combined mechanism glaucoma; TG, traumatic glaucoma; PXG, pseudoexfoliation glaucoma; PPG, pseudophakic glaucoma; CG, congenital glaucoma; SG, secondary glaucoma.

${ }^{a} 0$ indicates a value below the minimum detectable concentration.

at the concentrations attained with these two techniques are currently unknown, but in vitro and clinical investigations are being conducted to determine whether such exposure could adversely affect the endothelium.

This work was supported in part by a research grant from L. K. Whittier Foundation, South Pasadena, California, USA. The authors have no financial, commercial or proprietary interest in any of the products or companies mentioned in the study.

Key words: Endothelial cells, Episclera, HPLC, Scleral bed, Sponges.

\section{REFERENCES}

1. Wakaki S, Marumo $\mathrm{H}$, Tomioka $\mathrm{K}$, et al. Isolation of new fractions of antitumor mitomycins. Antibiot Chemother 1958;8:228-40.

2. Verweij J, Stoter G. Severe side effects of cytotoxic drug mitomycin-C. Neth J Med 1987;30:43-50.

3. Gilman AG, Rall TW, Nies AS, Taylor P, editors. Goodman and Gilman's The pharmacological basis of therapeutics. 8th ed. New York: Pergamon Press, 1990:1247-8.

4. Singh G, Wilson MR, Foster CS. Mitomycin eye drops as treatment for pterygium. Ophthalmology 1988;95:813-21.

5. Kunitomo N, Mori S. New treatment of pterygium. In: Acta XIX Concilium Ophthalmologicum. Bombay, India: K.Y.C. Pandit, 1962:1039-105.

6. Yamanouchi U. Scleral changes induced by instillation of mitomycin-C. Acta Med Nagasaki 1983;28:99-110.

7. Chen CW. Enhanced intraocular pressure controlling effectiveness of trabeculectomy by local application of mitomycin-C. Trans Asia-Pacific Acad Ophthalmol 1983;9:172-7.

8. Chen CW, Huang HT, Sheu MM. Enhancement of IOP con- trol effect of trabeculectomy by local application of anticancer drug. In: Blodi $\mathrm{F}$, Brancato $\mathrm{R}$, Cristini $\mathrm{G}$, et al. editors. Acta XXV Concilium Ophthalmologicum. Berhaly, Calif.: Kugler and Ghedini, 1987:1487-91.

9. Palmer SS. Mitomycin as adjunct chemotherapy with trabeculectomy. Ophthalmology 1991;98:317-21.

10. Talamo JH, Gollamudi S, Green WR, et al. Modulation of corneal wound healing after excimer laser keratomileusis using topical mitomycin $\mathrm{C}$ and steroids. Arch Ophthalmol 1991;109:1141-6.

11. Skuta GL, Beson CC, Higginbotham EJ, et al. Intraoperative mitomycin versus postoperative 5-fluorouracil in high-risk glaucoma filtering surgery. Ophthalmology 1992;99: 438-44.

12. Kitazawa Y, Kawase K, Matsushita H, Minobe M. Trabeculectomy with mitomycin: a comparative study with fluorouracil. Arch Ophthalmol 1991;109:1693-8.

13. Derick RJ, Pasquale L, Quigley HA, Jampel H. Potent toxicity of mitomycin C [letter]. Arch Ophthalmol 1991;109: 1635.

14. Rubinfeld RS, Pfister RR, Stein RM, et al. Serious complications of topical mitomycin-C after pterygium surgery 1992;99: 1647-54.

15. Fukamachi Y, Hikita N. Ocular complications following pterygium operation and instillation of mitomycin-C. Folia Ophthalmol Jpn 1981;32:197-201.

16. Yamanouchi U, Takaku I, Tsuda N, et al. Scleromalacia presumably due to mitomycin $\mathrm{C}$ instillation after pterygium excision. Jpn Clin Ophthalmol 1979;33:139-44.

17. Yamanouchi U, Mishima K. Ocular lesions due to mitomycin $\mathrm{C}$ instillation after pterygium operation. Folia Ophthalmol Jpn 1967;18:854-61.

18. Buice RG, Sidhu P, Gurley BJ, Niell HB. Reversed-phase high-performance liquid chromatographic determination of 
mitomycin C in human serum. Ther Drug Monit 1984;6: $113-5$.

19. Kono A, Hara Y, Eguchi S, et al. Determination of mitomycin $\mathrm{C}$ in biomedical specimens by high-performance liquid chromatography. J Chromatogr 1979;164:404-6.

20. Tjaden UR, Langenberg JP, Ensing K, Van Bennekom WP. Determination of mitomycin $\mathrm{C}$ in plasma, serum and urine by high-performance liquid chromatography with ultra- violet and electrochemical detection. J Chromatogr 1982; 232:355-67.

21. Kawase K, Matsushita H, Yamamoto T, Kitazawa Y. Mitomycin concentration in rabbit and human ocular tissues after topical administration. Ophthalmology 1992;99:203-7.

22. Falck FY, Skuta GL, Klein TB. Mitomycin versus 5-fluorouracil antimetabolite therapy for glaucoma filtration surgery. Semin Ophthalmol 1992;2:97-109. 